\title{
Особливостї суїцидальних намірів серед пацієнтів із когнітивними порушеннями при депресивних розладах
}

Мета - визначення особливостей суїцидальних намірів серед пацієнтів із когнітивними порушеннями при депресивних розладах. Об'єкт і методи дослідження. Обстежено 362 пацієнти з когнітивними порушеннями при депресивних розладах: 123 - з рекурентними депресивними розладами, 141 - з біполярними афективними розладами та 98 - із пролонгованою депресивною реакцією. Використовували клініко-психопатологічний, психометричний та статистичний методи дослідження. Результати. Визначені чинники суїцидального ризику у пацієнтів із когнітивними порушеннями при депресивних розладах, які включали особливості суїцидальних намірів, ідеаторні особливості суїцидальних думок та характеристики передбачувальної суїцидальної спроби. Висновки. Зазначені чинники суїцидального ризику можуть виступати як діагностичні критерії та враховуватися при створенні психокорекційних програм, спрямованих на редукцію суїцидального ризику.

Ключові слова: когнітивні порушення, депресивні розлади, суїцидальний ризик, рекурентний депресивний розлад, біполярний депресивний розлад, пролонгована депресивна реакція.

\section{Вступ}

Актуальність клінічного дослідження депресивних розладів (ДР) пов'язана з високою поширеністю депресії, її негативними соціальними, економічними та медичними наслідками (ВОЗ, 2014; Положий Б.С. и соавт., 2014; Wilcox H.C., Wyman P.A., 2016). Важливим аспектом ДР є те, що вони характеризуються рецидивуючим перебігом, схильністю до формування резистентних форм і становлять значну загрозу внаслідок розвитку ризику суїциду у цих хворих (Maruta N.O. et al., 2013; ВО3, 2014; Положий Б.C. и соавт., 2014; Khemakhem K. et al., 2017; Hoertel N. et al., 2017). Відомо, що суїцидальний ризик (СР) серед хворих, як перебувають на обліку у психоневрологічних диспансерах, у 35 разів вищий ніж у популяції психічно здорових осіб (Hetrick S.E. et al., 2012; Положий Б.С. и соавт., 2014; Hoertel N. et al., 2017). При цьому депресивний синдром - найбільш суїцидонебезпечний серед усіх психопатологічних синдромів (ВО3, 2014; Яковлева А.Л., Симуткин Г.Г., 2014; Трунов Д.Г., 2016; Протько Н.Н., 2017; Khemakhem K. et al., 2017;). До 10-15\% пацієнтів із ДР у результаті гинуть від самогубства (Nauta M.H. et al., 2012; BO3, 2014; Hoertel N. et al., 2017). 40-70\% пацієнтів із ДР мають думки про самогубство, а 90\% осіб, які вмирають у результаті самогубства, страждали від психічного розладу, найчастіше від депресії (Marshal M.P. et al., 2011; Корнетов H.A., 2013; Maruta N.O. et al., 2013; Положий Б.С. и соавт., 2014). Своєчасна діагностика ДР у багатьох випадках стає вирішальною умовою успішної медичної допомоги та профілактикою СР (Marshal M.P. et al., 2011; Hetrick S.E. et al., 2012; Васильев В.В. и соавт., 2014; Khemakhem K. et al., 2017). Однією з умов успішної профілактики суїциду при депресії є можливість досить точно оцінити СР у конкретного пацієнта з ДР (Guberman C., Manassis K., 2011; Wilcox H.C., Wyman P.A., 2016). Для цього необхідно мати чітке уявлення про найбільш суїцидонебезпечні клінічні характеристики і компоненти ДР (Balazs J., 2013; Khemakhem K. et al., 2017). Тим часом, саме в цьому питанні досі відсутня єдність поглядів (Положий Б.С., Панченко Е.А., 2012; Nauta M.H. et al., 2012; Tpyнов Д.Г., 2016; Wilcox H.C., Wyman P.A., 2016). Дані літератури, присвячені цьому питанню, відрізняються суперечливістю, різні автори висувають на перший план різні компоненти депресії (Краснов B.H., 2011; Hetrick S.E. et al., 2012; Nauta M.H. et al., 2012; Яковлева А.Л., Симуткин Г.Г., 2014; Трунов Д.Г., 2016; Протько Н.Н., 2017; Hoertel N. et al., 2017).

Мета - визначити особливості суїцидальних намірів серед пацієнтів із когнітивними порушеннями (КП) при ДР.

\section{Об"єкт ї методи дослідження}

У дослідженні взяли участь 362 пацієнти з КП при ДР: $123-$ з рекурентними ДР (РДР), 141 - з біполярними афективними розладами (БАР) та 98 - із пролонгованою депресивною реакцією (ПДР).

Серед обстежених пацієнтів із КП при РДР було 57 чоловіків $(46,34 \pm 2,78 \%)$ і 66 жінок $(53,66 \pm 2,99 \%)$, із БАР - $76(53,90 \pm 2,61 \%)$ та $65(46,10 \pm 2,42 \%)$, із ПДР $-43(43,88 \pm 3,39 \%)$ та $55(56,12 \pm 3,83 \%)$ відповідно, що в цілому відповідає типовому розподілу за статтю при ДР. 38, 12\% пацієнтів із КП при ДР були віком 30-44 роки. Осіб молодого віку (18-29 років) було більше серед пацієнтів із ПДР $(21,43 \%, Д К=8,19, \mathrm{Ml}=0,74 ; p=0,0001)$ та БАР $(31,21 \%$, ДК=9,82, $\mathrm{Ml}=1,37 ; p=0,0001)$, а осіб середнього (45-59 років) та похилого віку (60-65 років) - серед пацієнтів із РДР $(37,40 \%$, ДК $=1,54$, $\mathrm{Ml}=0,09 ; p=0,016$ та 17,07\%, ДК=4,78, Ml=0,27; $p=0,002$ відповідHO).

Для дослідження чинників суїцидальної поведінки (СП) при КП у пацієнтів із ДР використовували клініко-психопатологічний, психометричний (Шкала оцінки суїцидальних намірів (Suicide Intent Scale - SIS за A.T. Beck) та математико-статистичний методи дослідження (Кокун О.М. та співавт., 2019). Статистичну обробку даних застосовували для визначення середніх величин кількісних параметрів, їхніх стандартних помилок (у форматі \%£m\%), достовірності відмінностей (критерії Стьюдента, точний метод Фішера [t], Колмогорова - Смірнова $[\lambda])$. Статистичну обробку результатів проводили за допомогою програм «Excel-2010» та «Statistica 6.1».

\section{Результати та їх обговорення}

У $31,71 \%$ пацієнтів із РДР встановлено низький, у 40,65\% помірний, у 27,64\% - високий рівень СР. У $41,13 \%$ пацієнтів із БАР виявлено помірний, у 40,43\% - високий та у $18,44 \%$ - низький рівень СР. У 45,92\% пацієнтів із ПДР встановлено високий, у $36,73 \%$ - помірний та у $17,35 \%$ - низький рівень СР.

Статистичний аналіз результатів продемонстрував, що пацієнтів із низьким рівнем СР було більше при РДР $(31,71 \%)$ порівняно із хворими на БАР $(18,44 \%, Д К=2,35, \mathrm{Ml}=0,16 ; \mathrm{p}<0,0051)$ та ПДР $(17,35 \%$, ДК=2,62, Ml=0,196; $p<0,0062)$, серед яких переважали особи з високим рівнем СР $(40,43 \%$, ДК $=1,65, \mathrm{Ml}=0,11$; $\mathrm{p}<0,0096$ та 45,92\%, ДК=2,20, Ml=0,20; $\mathrm{p}<0,0021$ відповідно).

Проведений аналіз суїцидальних намірів серед пацієнтів із КП при ДР дозволив оцінити особливості їх суїцидального мислення (табл. 1-3). Як видно (див. табл. 1), у більшості пацієнтів із РДР 
Таблиця 1. Ставлення до життя/смерті серед пацієнтів із КП при ДР

\begin{tabular}{|c|c|c|c|c|c|c|}
\hline \multirow[b]{2}{*}{ Показник } & \multicolumn{2}{|c|}{ РДР (n=123) } & \multicolumn{2}{|c|}{$\operatorname{EAP}(n=141)$} & \multicolumn{2}{|c|}{ ПДР (n=98) } \\
\hline & $\begin{array}{c}\text { Абсолютне } \\
\text { число }\end{array}$ & $\% \pm m \%$ & $\begin{array}{c}\text { Абсолютне } \\
\text { число }\end{array}$ & $\% \pm m \%$ & $\begin{array}{c}\text { Абсолютне } \\
\text { число }\end{array}$ & $\% \pm m \%$ \\
\hline \multicolumn{7}{|c|}{ Бажання жити } \\
\hline Від помірного до сильного & 35 & $28,46 \pm 1,97$ & 17 & $12,06 \pm 0,81$ & 55 & $56,12 \pm 3,83$ \\
\hline Слабке & 68 & $55,28 \pm 3,03$ & 88 & $62,41 \pm 2,73$ & 31 & $31,63 \pm 2,70$ \\
\hline Відсутнє & 20 & $16,26 \pm 1,22$ & 36 & $25,53 \pm 1,57$ & 12 & $12,24 \pm 1,18$ \\
\hline \multicolumn{7}{|c|}{ Бажання померти } \\
\hline Відсутнє & 50 & $40,65 \pm 2,57$ & 19 & $13,48 \pm 0,90$ & 12 & $12,24 \pm 1,18$ \\
\hline Слабке & 44 & $35,77 \pm 2,35$ & 48 & $34,04 \pm 1,97$ & 31 & $31,63 \pm 2,70$ \\
\hline Від помірного до сильного & 29 & $23,58 \pm 1,69$ & 74 & $52,48 \pm 2,58$ & 55 & $56,12 \pm 3,83$ \\
\hline \multicolumn{7}{|c|}{ Докази на користь життя/смерті } \\
\hline Доказів на користь життя більше, ніж на користь смерті & 69 & $56,10 \pm 3,05$ & 63 & $44,68 \pm 2,37$ & 10 & $10,20 \pm 1,00$ \\
\hline Приблизно однакові & 48 & $39,02 \pm 2,50$ & 59 & $41,84 \pm 2,28$ & 56 & $57,14 \pm 3,86$ \\
\hline Доказів на користь смерті більше, ніж на користь життя & 6 & $4,88 \pm 0,39$ & 19 & $13,48 \pm 0,90$ & 32 & $32,65 \pm 2,76$ \\
\hline \multicolumn{7}{|c|}{ Бажання зробити активну суїцидальну спробу } \\
\hline Відсутнє & 27 & $21,95 \pm 1,59$ & 21 & $14,89 \pm 0,98$ & 10 & $10,20 \pm 1,00$ \\
\hline Слабке & 64 & $52,03 \pm 2,95$ & 53 & $37,59 \pm 2,12$ & 32 & $32,65 \pm 2,76$ \\
\hline Від помірного до сильного & 32 & $26,02 \pm 1,83$ & 67 & $47,52 \pm 2,46$ & 56 & $57,14 \pm 3,86$ \\
\hline Прийняв би запобіжних заходів, щоб залишитися в живих & 20 & $16,26 \pm 1,22$ & 11 & $7,80 \pm 0,54$ & 42 & $42,86 \pm 3,34$ \\
\hline Поклав би на волю випадку & 57 & $46,34 \pm 2,78$ & 71 & $50,35 \pm 2,53$ & 24 & $24,49 \pm 2,19$ \\
\hline Не зробив би нічого, щоб залишитися в живих & 46 & $37,40 \pm 2,43$ & 59 & $41,84 \pm 2,28$ & 32 & $32,65 \pm 2,76$ \\
\hline
\end{tabular}

відзначали слабке бажання жити (55,28ะ3,03\%), у 40,65\% - було відсутнє бажання померти, у 35,77\% осіб визначали слабке бажання померти, у 52,03\% пацієнтів було слабке бажання здійснити суїцидальну спробу. Хворі на РДР були схильні шукати докази на користь життя $(56,10 \pm 3,05 \%)$. При пасивній суїцидальній спробі 46,34\% пацієнтів поклалися би на волю випадку та 37,40\% не зробили би нічого, щоб залишитися у живих. У більшості пацієнтів із БАР $(62,41 \pm 2,73 \%)$ відзначали слабке бажання жити, вони відчували бажання померти, яке коливалося від помірного до сильного $(52,48 \pm 2,58 \%)$, намагалися знаходити докази на користь життя $(44,68 \pm 2,37 \%)$, але у $41,84 \%$ осіб доказів на користь життя та смерті було однаково. У 47,52\% осіб встановлено виражене бажання здійснити суїцидальну спробу, у 37,59\% це бажання було слабким. При пасивній суїцидальній спробі більшість пацієнтів

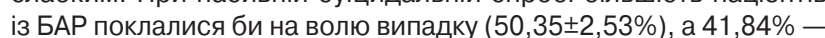
не зробили би нічого, щоб залишитися у живих. У більшості пацієнтів із ПДР відзначали протиріччя, що виражалось у наявності вираженого бажання жити $(56,12 \pm 3,83 \%)$ та вираженого бажання померти $(56,12 \pm 3,83 \%)$, більшість пацієнтів $(57,14 \pm 3,86 \%)$ відчували сильне бажання здійснити суїцидальну спробу.

Пацієнти з ПДР намагалися шукати докази на користь життя, але доказів на користь життя та смерті у більшості пацієнтів було

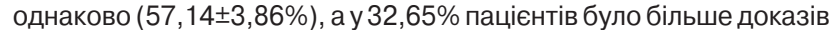
на користь смерті. При пасивній суїцидальній спробі більшість пацієнтів із ПДР були схильні вжити запобіжних заходів, щоб за-

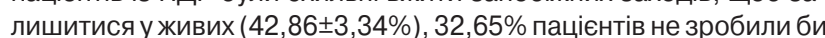
нічого, щоб залишитися у живих та $24,49 \%$ осіб поклались би на волю випадку.

Статистичний аналіз результатів дозволив довести, що серед пацієнтів із ПдР було більше осіб із вираженим бажанням жити та вираженим бажанням здійснити суїцидальну спробу $(56,12$ та $57,14 \%$ відповідно) порівняно з пацієнтами із РДР $(28,46 \%$, ДК=2,95, МІ=0,41; $<<0,0001$ та 26,02\%, ДК=3,42, MІ=0,53; $\mathrm{p}<0,0001$ відповідно) та БАР $(12,06 \%$, ДК=6,68, Ml=1,47; $\mathrm{p}<0,0001$ та $47,52 \%$, ДК=0,80, Мl=0,04; p<0,0361 відповідно). У пацієнтів із ПДР поряд із доводами за життя були однаково представлені доводи проти життя $(57,14 \%)$, а також було більше осіб, у яких переважали доводи за смерть (32,65\%) порівняно з пацієнтами на РДР $(39,02 \%$, ДК=1,66, Мl=0,15; $\mathrm{p}<0,003$ та $4,88 \%$, ДК=8,26, Ml=1,15; $\mathrm{p}<0,0001$ відповідно) та БАР $(41,84 \%$, ДК=1,35, Ml=0,10; $\mathrm{p}<0,007$ та 13,48\%, ДК=3,84, Мl=0,37; $p<0,0002$ відповідно). Пацієнти з ПДР відрізнялися також більшою кількістю осіб, готових вжити запобіжних заходів, щоб залишитися у живих $(42,86 \%)$ порівняно з пацієнтами з РДР та БАР (16,26\%, ДК=4,21, МІ=0,56; $\mathrm{p}<0,0001$ та 7,80\%, ДК=7,40, Мl=1,30; $p<0,0001$ відповідно).

Пацієнти з РДР відрізнялися від хворих на БАР та ПДР більшою кількістю осіб із відсутністю бажання померти $(40,65 \%$, ДК=4,80, $\mathrm{Ml}=0,65 ; \mathrm{p}<0,0001$ та ДК=5,21, Мl=0,74; $\mathrm{p}<0,0001$ відповідно), відсутністю та слабким бажанням здійснити суїцидальну спробу (21,95\%, ДК=1,68, МІ=0,06; $p<0,0427$ та ДК=3,33, Мl=0,20; $p<0,009$ та $52,03 \%$, ДК=1,41, МІ=0,10; $p<0,006$ та ДК=2,02, $M І=0,20$; $\mathrm{p}<0,0016$ відповідно) та переважанням доказів на користь життя (56,10\%, ДК=0,99, МІ=0,06; $\mathrm{p}<0,0178$ та ДК=7,40, MI=1,70; $\mathrm{p}<0,0001$ відповідно). Більшість пацієнтів із РДР у разі пасивної суїцидальної спроби поклалися би на волю випадку $(46,34 \%)$ порівняно з пацієнтами з ПДР $(24,49 \%$, ДК=2,77, Ml=0,30; $\mathrm{p}<0,0003)$.

Пацієнти з БАР відрізнялися більшою кількістю осіб із відсутністю бажання жити (25,53\%) порівняно з пацієнтами з РДР та ПДР (16,26\%, ДК=1,96, MІ=0,09; $p<0,0224$ та 12,24\%, ДК=3,19, MI=0,21; p $<0,005$ відповідно) та з вираженим бажанням померти та здійснити активну суїцидальну спробу (52,48 та 47,52\% відповідно) порівняно з пацієнтами з РДР $(23,58 \%$, ДК=3,48, Ml=0,50; $\mathrm{p}<0,0001$ та 26,02\%, ДК=2,62, Ml=0,28; p<0,0001 відповідно). Пацієнти з БАР відрізнялися від пацієнтів із ПДР більшою кількістю осіб зі слабким бажанням жити $(62,41 \%$, ДК=2,95 Ml=0,45; $p<0,0001)$, переважанням доказів на користь життя $(44,68 \%$, ДК=6,41, MI=1,11; $\mathrm{p}<0,0001)$ та відсутністю дій, щоб залишитися в живих у разі пасивної суїцидальної спроби або покладання на волю випадку (41,84\%, ДК=1,08, Мl=0,05; $p<0,0386$ та 50,35\%, ДК=3,13, Мl=0,40; p<0,0001 відповідно).

Аналізували особливості суїцидальної ідеаторної активності серед пацієнтів із КП при ДР (див. табл. 2). Визначено, що у більшості пацієнтів із РДР суїцидальні думки були досить тривалими $(61,79 \pm 3,13 \%)$, які періодично виникали та зникали $(52,85 \pm 2,97 \%)$, при цьому 63,41\% осіб не були впевнені, що зможуть протистояти суїцидальних думкам, а 30,08\% були впевнені у власному контролі над СП. Зауважимо, що у більшості пацієнтів із РДР відзначали негативне ставлення до суїцидальнихдумок $(65,04 \pm 3,15 \%)$ та 69,92\% осіб приймали до уваги стримувальні фактори: наявність сім'ї, релігійні переконання, можлива інвалідизація в разі неуспішної спроби, незворотність вчинку. Причиною можливої суїцидальної спроби у більшості пацієнтів із РДР було бажання покласти край стражданням, разом вирішити всі проблеми $(90,24 \pm 2,31 \%)$. у 46,10\% пацієнтів із БАР тривалість суїцидальних думок була невідступною, у 41,13\% - досить тривалою, суїцидальні думки у більшості пацієнтів були періодичними $(55,03 \pm 2,65 \%)$, у 40,43\% - постійними. у більшості пацієнтів із БАР ставлення до суїцидальних думок було індиферентним або нейтральним $(51,77 \pm 2,57 \%)$, у $1 / 3$ - негативним $(36,88 \pm 2,09 \%)$.

При цьому лише 29,79\% пацієнтів були впевнені у тому, що зможуть протистояти суїцидальним бажанням та намірам, $63,12 \%$ не впевнені, що зможуть утриматися від бажання вчинити суїцидальні дії. 54,61\% пацієнтів приймали до уваги стримувальні фактори: сім'я, релігійні переконання, можлива інвалідизація у разі безуспішної спроби, незворотність вчинку, а 30,50\% пацієнтів із БАР не схильні враховувати стримувальні фактори. Причиною можливої суїцидальної спроби у більшості пацієнтів із БАР було бажання покласти край стражданням, разом вирішити всі проблеми $(93,62 \pm 1,69 \%)$.

У $34,69 \%$ пацієнтів із ПДР суїцидальні думки були скороминущими, у 45,92\% - досить тривалими та у 19,39\% - невідступними. У більшості пацієнтів вони виникали періодично $(59,18 \pm 3,90 \%)$, 
Таблиця 2. Характеристика суїцидальної ідеаторної активності серед пацієнтів із КП при ДР

\begin{tabular}{|c|c|c|c|c|c|c|}
\hline \multirow[b]{2}{*}{ Показник } & \multicolumn{2}{|c|}{ РДР (n=123) } & \multicolumn{2}{|c|}{$\operatorname{5AP}(n=141)$} & \multicolumn{2}{|c|}{ ПДР (n=98) } \\
\hline & $\begin{array}{c}\text { Абсолютне } \\
\text { число }\end{array}$ & $\% \pm m \%$ & $\begin{array}{c}\text { Абсолютне } \\
\text { число }\end{array}$ & $\% \pm m \%$ & $\begin{array}{c}\text { Абсолютне } \\
\text { число }\end{array}$ & $\% \pm m \%$ \\
\hline \multicolumn{7}{|c|}{ Тривалість думок } \\
\hline Скороминущі & 24 & $19,51 \pm 1,43$ & 18 & $12,77 \pm 0,85$ & 34 & $34,69 \pm 2,89$ \\
\hline Досить тривалі & 76 & $61,79 \pm 3,13$ & 58 & $41,13 \pm 2,25$ & 45 & $45,92 \pm 3,48$ \\
\hline Невідступні & 23 & $18,70 \pm 1,38$ & 65 & $46,10 \pm 2,42$ & 19 & $19,39 \pm 1,79$ \\
\hline \multicolumn{7}{|c|}{ Частота } \\
\hline Виникають дуже рідко & 26 & $21,14 \pm 1,54$ & 5 & $3,55 \pm 0,25$ & 3 & $3,06 \pm 0,31$ \\
\hline Періодично то виникають, то зникають & 65 & $52,85 \pm 2,97$ & 79 & $56,03 \pm 2,65$ & 58 & $59,18 \pm 3,90$ \\
\hline Не відпускають & 32 & $26,02 \pm 1,83$ & 57 & $40,43 \pm 2,23$ & 37 & $37,76 \pm 3,07$ \\
\hline \multicolumn{7}{|c|}{ Ставлення до суїцидальних думок/бажань } \\
\hline Негативне & 80 & $65,04 \pm 3,15$ & 52 & $36,88 \pm 2,09$ & 75 & $76,53 \pm 3,82$ \\
\hline Амбівалентне або індиферентне & 32 & $26,02 \pm 1,83$ & 73 & $51,77 \pm 2,57$ & 20 & $20,41 \pm 1,88$ \\
\hline Позитивне & 11 & $8,94 \pm 0,70$ & 16 & $11,35 \pm 0,76$ & 3 & $3,06 \pm 0,31$ \\
\hline \multicolumn{7}{|c|}{ Контроль над СП } \\
\hline Упевнений, що може протистояти суїцидальним думкам/бажанням & 37 & $30,08 \pm 2,06$ & 42 & $29,79 \pm 1,78$ & 55 & $56,12 \pm 3,83$ \\
\hline Не впевнений у цьому & 78 & $63,41 \pm 3,14$ & 89 & $63,12 \pm 2,74$ & 36 & $36,73 \pm 3,01$ \\
\hline Не контролює себе & 8 & $6,50 \pm 0,52$ & 10 & $7,09 \pm 0,49$ & 7 & $7,14 \pm 0,71$ \\
\hline Не зробить самогубства у зв'язку зі стримувальними факторами & 14 & $11,38 \pm 0,88$ & 21 & $14,89 \pm 0,98$ & 56 & $57,14 \pm 3,86$ \\
\hline Приймає до уваги стримувальні фактори & 86 & $69,92 \pm 3,14$ & 77 & $54,61 \pm 2,63$ & 33 & $33,67 \pm 2,83$ \\
\hline Не думає про стримувальні фактори & 23 & $18,70 \pm 1,38$ & 43 & $30,50 \pm 1,82$ & 9 & $9,18 \pm 0,90$ \\
\hline \multicolumn{7}{|c|}{ Причини передбачуваної суїцидальної спроби } \\
\hline Маніпулювати оточуючими, привернути до себе увагу, помститися комусь & 3 & $2,44 \pm 0,20$ & 2 & $1,42 \pm 0,10$ & 5 & $5,10 \pm 0,51$ \\
\hline Покласти край стражданням, разом вирішити всі проблеми & 111 & $90,24 \pm 2,31$ & 132 & $93,62 \pm 1,69$ & 78 & $79,59 \pm 3,71$ \\
\hline Поєднання наведених варіантів & 9 & $7,32 \pm 0,58$ & 7 & $4,96 \pm 0,35$ & 15 & $15,31 \pm 1,45$ \\
\hline
\end{tabular}

у $37,76 \%$ - були нав'язливими. У більшості пацієнтів ставлення

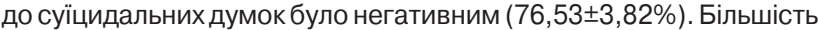
пацієнтів були впевнені, що зможуть протистояти суїцидальним думкам чи бажанням та $36,73 \%$ - не впевнені в цьому. Стримувальні фактори були визначальними для більшості пацієнтів із ПДР $(57,14 \pm 3,86 \%), 33,67 \%$ пацієнтів схильні враховувати їх Причиною можливої суїцидальної спроби у більшості пацієнтів із ПДР було бажання покласти край стражданням, разом вирішити всі проблеми $(79,59 \pm 3,71 \%)$

Статистичний аналіз результатів дозволив визначити, що серед пацієнтів із РДР частка осіб, у яких суїцидальні думки виникали дуже рідко $(21,14 \%)$, була більшою ніж серед пацієнтів із БАР та ПДР $(3,55 \%$, ДК=7,75, Ml=0,68; $<<0,0001$ та $3,06 \%$, ДК=8,39, MI=0,76; $p<0,0001$ відповідно), у яких було більше осіб з нав'язливими суїцидальними думками $(40,43 \%$, ДК $=1,91$, $\mathrm{Ml}=0,14 ; p<0,004$ та 37,76\%, ДК=1,62, Ml=0,09; $p<0,0204$ відповідно). Доведено, що у пацієнтів із ПДР було більше осіб, у яких суїцидальні думки були скороминущі $(34,69 \%)$ порівняно з пацієнтами з РДР та БАР $(19,51 \%$, ДК=2,50, MI=0,19; $p<0,004$ та $12,77 \%$, ДК=4,34, MI=0,48; $\mathrm{p}<0,0001$ відповідно); серед пацієнтів із РДР переважали особи з досить тривалими суїцидальними думками $(61,79 \%)$ порівняно з пацієнтами з БАР та ПДР $(41,13 \%$, ДК=1,77, $\mathrm{Ml}=0,18 ; \mathrm{p}<0,0003$ та 45,92\%, ДК=1,29, $\mathrm{MI}=0,10$; p $<0,0068$ відповідно); серед пацієнтів із БАР переважали особи 3 невідступними суїцидальними думками $(46,10 \%)$ порівняно 3 пацієнтами з РДР та ПДР $(18,70 \%$, ДК=3,92, MI=0,54; $\mathrm{p}<0,0001$ та 19,39\%, ДК=3,76, Ml=0,50; $<<0,0001$ відповідно).

Негативне ставлення до суїциду переважало серед пацієнтів із ПДР $(76,53 \%)$ на відміну від пацієнтів із РДР та БАР $(65,04 \%$, ДК=0,71, $\mathrm{Ml}=0,04 ; \mathrm{p}<0,0213$ та $36,88 \%$, ДК=3,17, $\mathrm{Ml}=0,63$ $\mathrm{p}<0,0001$ відповідно), серед яких було більше осіб із позитивним ставленням до суїциду $(8,94 \%$, ДК=4,66, MI=0,14; $p<0,0470$ та $11,35 \%$, ДК=5,69, $\mathrm{Ml}=0,24 ; \mathrm{p}<0,0120$ відповідно), а пацієнти з БАР відрізнялися від хворих на РДР та ПДР переважанням амбівалентного ставлення до суїциду $(51,77 \%$, ДК $=2,99, \mathrm{MI}=0,38$ $\mathrm{p}<0,0001$ та ДK=4,04, Ml=0,46; $\mathrm{p}<0,0001$ відповідно). Також зазначимо, що негативне ставлення до суїциду більш виражене серед пацієнтів із РДР $(65,04 \%)$ на відміну від пацієнтів із БАР $(36,88 \%, Д К=2,46, M l=0,35 ; p<0,0001)$.

Доведено, що пацієнти з ПДР відрізнялися більш вираженою впевненістю щодо контролю та протистояння суїцидальним думкам $(56,12 \%)$ порівняно 3 пацієнтами з РДР та БАР $(30,08 \%$, ДК=2,71, $\mathrm{Ml}=0,35 ; \mathrm{p}<0,0001$ та 29,79\%, ДК=2,75, $\mathrm{Ml}=0,36$; $\mathrm{p}<0,0001$ відповідно), в яких було більше осіб із наявністю сумнівів щодо протистояння суїцидальним думкам та бажанням $(63,41 \%, Д К=2,37, \mathrm{Ml}=0,32 ; \mathrm{p}<0,0001$ та $63,12 \%, Д К=2,35, \mathrm{Ml}=0,31$; $\mathrm{p}<0,0001$ відповідно)
Виявлено, що стримувальні фактори, такі як наявність сім'ї, релігійні переконання, можлива інвалідизація у разі безуспішної спроби, незворотність вчинку більше впливали на пацієнтів із ПДР $(57,14 \%)$ на відміну від хворих на РДР та БАР $(11,38 \%$, ДК $=7,01$, $\mathrm{Ml}=1,60 ; \mathrm{p}<0,0001$ та $14,89 \%$, ДК=5,84, Ml=1,23; $\mathrm{p}<0,0001$ відповідно), які схильні були не зважати на стримувальні фактори $(18,70 \%, Д К=3,09, M l=0,15 № ~ p<0,0210$ та $30,50 \%$, ДК=5,21, $\mathrm{Ml}=0,56 ; p<0,0001$ відповідно) та приймати їх до уваги $(69,92 \%$, ДК=3,17, MI=0,58; $\mathrm{p}<0,0001$ та 54,61\%, ДК=2,10, $\mathrm{Ml}=0,22$; $\mathrm{p}<0,0006$ відповідно). При цьому зазначимо, що серед пацієнтів із РДР було більше осіб, які враховували стримувальні фактори $(69,92 \%)$ на відміну від пацієнтів із БАР $(54,61 \%$, ДК=1,07, Ml=0,08; $\mathrm{p}<0,0038)$, серед яких було більше осіб, які не зважали на стримувальні фактори $(30,50 \%$, ДК=2,12, MI=0,13; $\mathrm{p}<0,0099)$.

У результаті статистичного аналізу доведено, що причиною можливої суїцидальної спроби у більшості пацієнтів із РДР та БАР було бажання покласти край стражданням (90,24 та 93,62\% відповідно) на відміну від пацієнтів із ПДР (79,59\%, ДК=0,55, Ml=0,03; $\mathrm{p}<0,0130$ та ДК=0,70, Ml=0,05; $<<0,0008$ відповідно), серед яких було більше осіб із поєднанням бажання маніпулювання та вирішення проблеми $(15,31 \%$, ДК=3,21, Ml=0,13; $p<0,0295$ та ДК=4,89, $\mathrm{Ml}=0,25 ; p<0,0049$ відповідно).

Аналіз характеристикпередбачуваної суїцидальної спроби серед пацієнтів із КПпри ДР дозволив визначити, що середпацієнтів із РДР у 43,90\% суїцидальні наміри не були продумані, у 54,47\% вони були обмірковані у загальному вигляді (див. табл. 3). Визначено, що для підготовки до суїцидальної спроби у $68,29 \%$ пацієнтів був необхідний час, у $21,95 \%$ доступність методу або можливості була відсутня. Оцінка суб'єктивного відчуття до здійснення суїциду дозволила встановити, що більшість пацієнтів із РДР не були впевнені в тому, що їм вистачить сміливості або компетентності, щоб убити себе $(59,35 \pm 3,10 \%), 30,08 \%$ вважали, що їм не вистачить сміливості здійснити суїцидальну спробу. 48,78\% осіб із РДР мали сумнівищодо можливості скоєння суїциду, 45,53\% не мали передбачення суїцидальної спроби. Більшість пацієнтів із РДР не схильні були здійснювати реальної підготовки до можливого суїциду $(87,80 \pm 2,51 \%)$, не мали передсмертної записки (100\%), не схильні були реалізовувати останні дії та розпорядження $(98,37 \pm 1,03 \%)$. Приховування суїцидальних намірів не було характерним для пацієнтів із РДР: 26,02\% відкрито висловлювали їх, 72,36\% про них не говорили та лише 1,63\% мали схильність приховувати їх.

Оцінка передумов суїцидальної спроби дозволила встановити, що у більшості пацієнтів із РДР не відзначені суїцидальні спроби у минулому $(95,12 \pm 1,72 \%)$

Аналіз характеристик передбачуваної суїцидальної спроби серед пацієнтів із КП при БАР дозволив визначити, що у $31,91 \%$ пацієнтів не були схильні обмірковувати суїцидальні наміри, 
Таблиця 3. Характеристики передбачуваної суїцидальної спроби серед пацієнтів із КП при ДР

\begin{tabular}{|c|c|c|c|c|c|c|}
\hline \multirow[b]{2}{*}{ Показник } & \multicolumn{2}{|c|}{ РДР $(n=123)$} & \multicolumn{2}{|c|}{ БAP $(n=141)$} & \multicolumn{2}{|c|}{ ПДР $(n=98)$} \\
\hline & $\begin{array}{c}\text { Абсолютне } \\
\text { число }\end{array}$ & $\% \pm m \%$ & $\begin{array}{l}\text { Абсолютне } \\
\text { число }\end{array}$ & $\% \pm m \%$ & $\begin{array}{l}\text { Абсолютне } \\
\text { число }\end{array}$ & $\% \pm m \%$ \\
\hline \multicolumn{7}{|c|}{ Метод: ступінь продуманості } \\
\hline Не обміркований & 54 & $43,90 \pm 2,70$ & 45 & $31,91 \pm 1,88$ & 23 & $23,47 \pm 2,12$ \\
\hline Обміркований у загальному вигляді & 67 & $54,47 \pm 3,01$ & 62 & $43,97 \pm 2,35$ & 68 & $69,39 \pm 3,96$ \\
\hline Детально опрацьовано & 2 & $1,63 \pm 0,13$ & 34 & $24,11 \pm 1,50$ & 7 & $7,14 \pm 0,71$ \\
\hline \multicolumn{7}{|c|}{ Ступінь доступності методу і наявність можливості для здійснення суїциду } \\
\hline Недоступний у принципі; можливість відсутня & 27 & $21,95 \pm 1,59$ & 30 & $21,28 \pm 1,35$ & 23 & $23,47 \pm 2,12$ \\
\hline Для підготовки потрібен час; зараз можливість відсутня & 84 & $68,29 \pm 3,15$ & 92 & $65,25 \pm 2,75$ & 64 & $65,31 \pm 3,97$ \\
\hline Метод перебуває за межами покритяя; можливість Є & 12 & $9,76 \pm 0,76$ & 19 & $13,48 \pm 0,90$ & 11 & $11,22 \pm 1,09$ \\
\hline \multicolumn{7}{|c|}{ Суб'єктивно відчувається здатність до здійснення суїциду } \\
\hline Вважає, що йому не вистачить сміливості або що у нього не вийде вбити себе & 37 & $30,08 \pm 2,06$ & 41 & $29,08 \pm 1,75$ & 29 & $29,59 \pm 2,56$ \\
\hline $\begin{array}{l}\text { Не впевнений у тому, що йому вистачить сміливості або компетентності, } \\
\text { щоб убити себе }\end{array}$ & 73 & $59,35 \pm 3,10$ & 83 & $58,87 \pm 2,70$ & 59 & $60,20 \pm 3,92$ \\
\hline Упевнений у власній сміливості й компетентності & 13 & $10,57 \pm 0,82$ & 17 & $12,06 \pm 0,81$ & 10 & $10,20 \pm 1,00$ \\
\hline \multicolumn{7}{|c|}{ Очікування/передбачення суїцидальної спроби } \\
\hline Немає & 56 & $45,53 \pm 2,75$ & 47 & 1,94 & 62 & $63,27 \pm 3,95$ \\
\hline Слабке; під сумнівом & 60 & $48,78 \pm 2,86$ & 79 & $56,03 \pm 2,65$ & 30 & $30,61 \pm 2,63$ \\
\hline Наявне & 7 & $5,69 \pm 0,45$ & 15 & $10,64 \pm 0,72$ & 6 & $6,12 \pm 0,61$ \\
\hline \multicolumn{7}{|c|}{ Реалізація передбачуваного суїциду } \\
\hline \multicolumn{7}{|c|}{ Реальна підготовка } \\
\hline Немає & 108 & $87,80 \pm 2,51$ & 122 & $\pm 2,27$ & 76 & $77,55 \pm 3,79$ \\
\hline Часткова (почав запасатися таблетками тощо) & 15 & $12,20 \pm 0,94$ & 17 & $12,06 \pm 0,81$ & 21 & $21,43 \pm 1,96$ \\
\hline Завершена (має достатній запас таблеток, заряджений пістолет тощо) & 0 & & 2 & $1,42 \pm 0,10$ & 1 & $1,02 \pm 0,10$ \\
\hline \multicolumn{7}{|c|}{ Передсмертна записка } \\
\hline Немає & 123 & 100,0 & 141 & 100,0 & 98 & 100,0 \\
\hline Тільки обмірковує & 0 & & 0 & & 0 & \\
\hline Написана & 0 & & 0 & & 0 & \\
\hline \multicolumn{7}{|c|}{ Останні дії та розпорядження } \\
\hline Немає & 121 & $98,37 \pm 1,03$ & 137 & $97,16 \pm 1,17$ & 93 & $94,90 \pm 2,21$ \\
\hline Думає про це; зробив деякі розпорядження & 2 & $1,63 \pm 0,13$ & 4 & $2,84 \pm 0,20$ & 4 & $4,08 \pm 0,41$ \\
\hline Зробив всі необхідні розпорядження & 0 & & 0 & & 1 & $1,02 \pm 0,10$ \\
\hline \multicolumn{7}{|c|}{ Приховування суїцидальних намірів } \\
\hline Висловлює їх відкрито & 32 & $26,02 \pm 1,83$ & 54 & $38,30 \pm 2,15$ & 34 & $34,69 \pm 2,89$ \\
\hline Не говорить про них & 89 & $72,36 \pm 3,12$ & 72 & $51,06 \pm 2,55$ & 64 & $65,31 \pm 3,97$ \\
\hline Приховує їх & 2 & $1,63 \pm 0,13$ & 15 & $10,64 \pm 0,72$ & 1 & $1,02 \pm 0,10$ \\
\hline \multicolumn{7}{|c|}{ Передумови для здійснення суїциду } \\
\hline \multicolumn{7}{|c|}{ Наявність суїцидальних спроб у минулому } \\
\hline Немає & 117 & $95,12 \pm 1,72$ & 122 & $86,52 \pm 2,27$ & 97 & $98,98 \pm 1,03$ \\
\hline Одна & 6 & $4,88 \pm 0,39$ & 15 & $10,64 \pm 0,72$ & 1 & $1,02 \pm 0,10$ \\
\hline Кілька & 0 & & 4 & $2,84 \pm 0,20$ & 0 & \\
\hline \multicolumn{7}{|c|}{ Бажання померти після останньої суїцидальної спроби } \\
\hline Слабке & 5 & $4,07 \pm 0,33$ & 9 & $6,38 \pm 0.44$ & 1 & $1,02 \pm 0,10$ \\
\hline Амбівалентні почуття & 1 & $0,81 \pm 0,07$ & 10 & $7,09 \pm 0,49$ & 0 & 0 \\
\hline Сильне & 0 & 0 & 0 & 0 & 0 & 0 \\
\hline
\end{tabular}

43,97\% схильні обмірковувати суїцидальні думки в загальному вигляді та у 24,11\% суїцидальні наміри були детально продумані.

Визначено, що для підготовки до суїцидальної спроби у 65,25\% пацієнтів був необхідний час, у 21,28\% доступність методу або можливості були відсутні та у 13,48\% були можливості для скоєння суїциду. Більшість пацієнтів із БАР виражали сумнів щодо сміливості або компетентності у можливій спробі скоєння суїциду $(58,87 \pm 2,70 \%), 29,08 \%$ осіб були впевнені, що в них не вистачить сміливості та 12,06\% були впевнені, що їм вистачить сміливості для скоєння суїциду. Більшість осіб із БАР мали сумніви щодо можливості скоєння суїциду $(56,03 \pm 2,65 \%), 33,33 \%$ не мали передбачення суїцидальної спроби. Оцінка реалізації передбачуваного суїциду продемонструвала, що більшість пацієнтів із БАР не планували реальної підготовки до суїциду $(86,52 \pm 2,27 \%)$ : не писали передсмертних записок (100\%) та не здійснювали останніх дій та розпоряджень $(97,16 \pm 1,17 \%)$. Також встановлено, що 38,30\% не мали суїцидальних намірів або висловлювали їх відкрито, 51,06\% пацієнтів не були схильні говорити про них та 10,64\% схильні були їх приховувати. Аналіз передумов суїцидальної спроби дозволив встановити, що у більшості пацієнтів із БАР не зареєстровані суїцидальні спроби у минулому (86,52ะ2,27\%), у 10,64\% була одна суїцидальна спроба в минулому, при цьому у 6,38 та 7,09\% пацієнтів відповідно відзначали слабке та амбівалентне бажання померти після останньої суїцидальної спроби.

Оцінка характеристик передбачуваної суїцидальної спроби серед пацієнтів із КП при ПДР дозволила визначити, що за ступенем продуманості суїцидальних намірів у 23,47\% пацієнтів суїцидальні наміри були необмірковані, у 69,39\% - обмірковані в загальному вигляді та у 7,14\% - детально опрацьовані. За ступенем доступності методу та наявності можливості скоєння суїциду визначено, що для 23,47\% пацієнтів ця можливість була відсутня, для 65,31\% був потрібен час для підготовки та у $11,22 \%$ ця можливість була доступною. Суб'єктивне відчуття здатності здійснення суїциду розподілилися таким чином: 29,59\% пацієнтів вважали, що їм не вистачить сміливості, 60,20\% були не впевнені в тому, що їм вистачить сміливості та компетентності, щоб убити себе, та 10,20\% мали впевненість у власних силах щодо можливості скоєння суїциду. 30,61\% осіб із ПДР мали сумніви щодо можливості скоєння суїциду, 63,27\% не мали передбачення суїцидальної спроби. Оцінка реалізації передбачуваного суїциду продемонструвала, що більшість пацієнтів із ПдР не були схильні здійснювати реальну підготовку до можливого суїциду $(77,55 \pm 3,79 \%)$, не мали передсмертної записки (100\%), не були схильні реалізо-

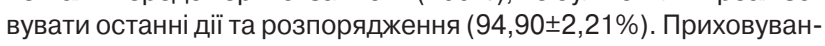
ня суїцидальних намірів не було характерним для 34,69\% пацієнтів із ПДР, 65,31\% про них не говорили та лише 1,02\% мали схильність приховувати суїцидальні наміри. Оцінка передумов суїцидальної спроби дозволила встановити, що у більшості пацієнтів із ПДР не зареєстровані суїцидальні спроби у минулому $(98,98 \pm 1,03 \%)$.

Статистичний аналіз результатів дозволив визначити, що серед пацієнтів із РДР було більше осіб із необміркованими суїцидальними намірами (43,90\%) порівняно з пацієнтами з БАР та ПДР $(31,91 \%$, ДК=1,38, MI=0,08; $p<0,0136$ та 23,47\%, ДК=2,72, $\mathrm{Ml}=0,28 ; p<0,0007$ відповідно), серед яких було більше пацієнтів з детально обміркованими суїцидальними намірами $(24,11 \%$, ДК=11,71, МІ=1,32; $p<0,0001$ та $7,14 \%$, ДК=6,43, МІ=0,18; $\mathrm{p}<0,0353$ відповідно). Зазначимо, що схильність обмірковувати в загальному вигляді була більш характерна для пацієнтів із ПдР $(69,39 \%)$ ніж для пацієнтів із РДР та БАР $(54,47 \%$, ДК=1,05, Ml=0,08; $\mathrm{p}<0,0086$ та 43,97\%, ДК=1,98, Ml=0,06; $\mathrm{p}<0,0001$ відповідно) та пацієнтів із РДР $(54,47 \%)$ порівняно із хворими на БАР $(43,97 \%$, 
ДК=0,93, MI=0,05; p<0,0232). Пацієнти з БАР відрізнялися від хворих на ПДР більшою кількістю осіб, що не були схильні обмірковувати взагалі суїцидальні наміри $(31,91 \%$, ДК=1,33, MI=0,06; $\mathrm{p}<0,0427)$, а також тих, хто це робив детально $(24,11 \%$, ДК $=5,28$, $\mathrm{Ml}=0,45 ; \mathrm{p}<0,0002)$.

Доведено, що пацієнти з РДР та ПДР більшою мірою характеризувалися відсутністю передбачення суїцидальних спроб (45,53 та $63,27 \%$ відповідно) на відміну від пацієнтів із БАР $(33,33 \%$, ДК=1,35, Ml=0,08; $p<0,0130$ та ДК=2,78, Ml=0,42; $p<0,0001$ відповідно), для яких більш характерно відчувати сумнів щодо передбачення суїцидальної спроби $(56,03 \%$, ДК=0,60, MI=0,02; $\mathrm{p}<0,0494$ та ДК=2,63, Ml=0,33; $p<0,0001$ відповідно). Також зазначимо, що серед пацієнтів із ПДР було більше осіб, не схильних очікувати суїцидальні спроби $(63,27 \%)$ порівняно з пацієнтами з РДР $(45,53 \%$, ДК=1,43, MI=0,13; $p<0,0034)$, серед яких було більше осіб зі слабким відчуттям передбачуваності суїциду $(48,78 \%$, ДК=2,02, MI=0,18; $p<0,0026)$

Встановлено, що серед пацієнтів із ПДР було більше осіб із частковою підготовкою до суїциду $(21,43 \%)$ порівняно з пацієнтами з РДР та БАР $(12,20 \%$, ДК $=2,45, \mathrm{Ml}=0,11 ; \mathrm{p}<0,0270$ та $12,06 \%$, ДК=2,50, Ml=0,12; $p<0,0220$ відповідно), серед яких було більше осіб з відсутністю реальної підготовки до суїциду $(87,80 \%$, ДК=0,54, $\mathrm{MI}=0,03 ; p<0,0189$ та 86,52\%, ДК=0,48, $\mathrm{MI}=0,02$; $\mathrm{p}<0,0274$ відповідно)

Статистичний аналіз особливостей приховування суїцидальних намірів дозволив довести, що відкрито висловлювати власні суїцидальні думки більш характерно для пацієнтів із ПДР та БАР (34,69 та 38,30\% відповідно) порівняно із хворими на РДР $(26,02 \%$, ДК=1,25, Ml=0,05; $p<0,0443$ та ДК=1,68, Ml=0,10; $p<0,0110$ відповідно); не говорити про них більш характерно для пацієнтів із ПДР та РДР (72,36 та 65,31\% відповідно) порівняно з пацієнтами з БАР $(51,06 \%, Д К=1,51, \mathrm{Ml}=0,16 ; p<0,0001$ та ДК=1,07, $\mathrm{Ml}=0,08$; $\mathrm{p}<0,009$ відповідно), для яких більш характерно приховувати суїцидальні думки $(10,64 \%$, ДК=8,16, MІ=0,37; $p<0,001$ та ДК=10,18, $\mathrm{Ml}=0,45 ; p<0,0018$ відповідно).

Статистичний аналіз передумов суїцидальної спроби дозволив встановити, що у більшості пацієнтів із РДР та ПДР не зареєстровані суїцидальні спроби у минулому $(95,12$ та 98,98\% відповідно) порівняно з пацієнтами з БАР $(86,52 \%$, ДК=0,41, МІ=0,02; $\mathrm{p}<0,0097$ та ДК=0,58, Ml=0,04; $\mathrm{p}<0,0002$ відповідно), серед яких було більше осіб з однією суїцидальною спробою в анамнезі $(10,64 \%, Д К=3,39, M I=0,10 ; p<0,0421$ та ДК=10,18, MI=0,45; $\mathrm{p}<0,0018$ відповідно). Також встановлено, що пацієнтів, які відчували слабке бажання померти після останньої суїцидальної спроби, більше серед осіб з БАР (6,38\%), на відміну від пацієнтів із ПДР $(1,02 \%$, ДК=7,87, Ml=0,21; $p<0,0354)$, а також серед пацієнтів із БАР більше осіб з амбівалентним бажанням померти після останньої суїцидальної спроби $(7,09 \%)$ порівняно з пацієнтами з РДР та ПДР (ДК=9,49, Мl=0,29; $p<0,007$ та $p<0,0048$ відповідно).

\section{Висновки}

Визначені диференційовані особливості СР серед пацієнтів із КП при ДР.

У пацієнтів із РДР особливості СП визначалися:

- переважанням помірного та низького рівнів СР;

- особливостями суїцидальних намірів (переважанням слабкого бажання жити та відсутністю бажання померти, переважанням доказів за життя, слабкого бажання здійснити активну суїцидальну спробу, покладання на випадок у разі пасивної суїцидальної спроби);

- ідеаторними особливостями суїцидальних думок (переважанням тривалих та періодичних суїцидальних думок, негативним ставленням до них, невпевненістю у можливості їх проконтролювати, прийняттям до уваги стримувальних факторів та переважанням бажання закінчити страждання);

- характеристиками передбачувальної суїцидальної спроби (переважанням необміркованості та обміркованості в загальному вигляді майбутніх суїцидальних спроб, необхідністю їх підготовки, невпевненістю у спроможності здійснити суїцидальну спробу, відсутністю та слабким передбаченням суїцидальної спроби, відсутністю реальної підготовки, передсмертної записки, останніх розпоряджень та відкритих висловлювань щодо суїцидальних намірів та відсутність попередніх спроб у минулому)
У пацієнтів із БАР особливості СП визначалися:

- переважанням помірного та вираженого рівнів СР;

- особливостями суїцидальних намірів (переважанням слабкого бажання жити та сильного бажання померти або здійснити активну суїцидальну спробу, переважання доказів за життя, покладання на випадок або відсутність запобіжних заходів у разі пасивної суїцидальної спроби);

- ідеаторними особливостями суїцидальнихдумок (переважанням нав'язливих та постійних суїцидальних думок, нейтральним або амбівалентним ставленням до них, невпевненістю у можливості їх проконтролювати, прийняттям до уваги або ігноруванням стримувальних факторів та переважанням бажання закінчити страждання);

- характеристиками передбачувальної суїцидальної спроби (переважанням необміркованості та обміркованості в загальному вигляді майбутніх суїцидальних спроб, необхідністю їх підготовки, невпевненістю у спроможності здійснити суїцидальну спробу, слабким передбаченням суїцидальної спроби, відсутністю реальної підготовки, передсмертної записки, останніх розпоряджень, попередніх спроб у минулому та відкритих висловлювань щодо суїцидальних намірів).

У пацієнтів із ПДР особливості СП визначалися:

- переважанням вираженого рівня СР;

- особливостями суїцидальних намірів (переважанням сильного бажання жити поряд із сильним бажанням померти або здійснити активну суїцидальну спробу, амбівалентність доказів «за» та «проти» життя, прийняття запобіжних заходів у разі пасивної суїцидальної спроби);

- ідеаторними особливостями суїцидальних думок (переважанням скороминучих і тривалих суїцидальних думок, періодичного та постійного характеру, негативним ставленням до них, впевненістю у можливості їх проконтролювати, важливістю стримувальних факторів та переважанням бажання вирішити проблеми, поєднанні з маніпулюванням);

- характеристиками передбачувальної суїцидальної спроби (переважанням обміркованості в загальному вигляді майбутніх суїцидальних спроб, необхідністю їх підготовки, невпевненістю у спроможності здійснити суїцидальну спробу, відсутністю очікування суїцидальної спроби, відсутністю реальної підготовки, передсмертної записки, останніх розпоряджень, попередніх спробу минулому та відкритих висловлювань щодо суїцидальних намірів)

Таким чином, у результаті дослідження визначені особливості СП у пацієнтів із КП при ДР, які можуть виступати як діагностичні критерії при проведенні диференційної діагностики та можуть враховуватися при створенні психокорекційних програм, спрямованих на редукцію СР у пацієнтів із КП при ДР.

\section{Список використаної літератури}

Васильев В.В., Ковалев Ю.В., Имашева Э.Р. (2014) Суицидальные мысли при депрессивном синдроме. Суицидология, 1(14): 30-35.

B03 (2014) Предотвращение самоубийств. Глобальный императив (https:// www.who.int/mental_health/suicide-prevention/world_report_2014/ru/).

Кокун О.М., Агаєв Н.А., Пішко І.О. та ін. (2019) Психологічна оцінка суїцидального ризику у військовослужбовців. Київ, НДЦ ГП ЗСу, 206 с.

Корнетов Н.А. (2013) Мультиаспектная модель профилактики суицидов. Тюмен. мед. журн., 15 (1): 11-12 (https://cyberleninka.ru/article/n/ multiaspektnaya-model-profilaktiki-suitsidov).

Краснов В.Н. (2011) Расстройства аффективного спектра. Практ. мед., Москва, 432 с.

Положий Б.С., Панченко Е.А. (2012) Дифференцированная профилактика суицидального поведения. Суицидология, 3(1): 8-12

Положий Б.С., Фритлинский В.С., Агеев С.Е. (2014) Суициды в странах СНГ. Суицидология, 5(4): 12-16.

Протько Н.Н. (2017) Психические расстройства и суициды. Психиатр. психотер. клин. психол., 3: 134-144.

Трунов Д.Г. (2016) Определение суицида: поиск критериев. Суицидология, 7(1): 64-67.

Яковлева А.Л., Симуткин Г.Г. (2014) Влияние коморбидности аффективных и личностных расстройств на основные клинические характеристики текущего депрессивного эпизода и суицидальное поведение. Суицидология, 5(3): 47-52.

Balazs J. (2013) Adolescent subthreshold-depression and anxiety: psychopathology, functional impairment and increased suicide risk. J. Child Psychol. Psychiatr., 54(6): 670-677. DOI: 10.1111/jcpp.12016. 
Guberman C., Manassis K. (2011) Symptomatology and family functioning in children and adolescents with comorbid anxiety and depression. J. Canadian Acad. Child Adoles. Psychiatr., 20(3): 186-195.

Hetrick S.E., Parker A.G., Robinson J. et al. (2012) Predicting suicida risk in a cohort of depressed children and adolescents. Crisis: J. Crisis Interv. Suic. Prev., 33(1): 13-20 (https://doi.org/10.1027/0227-5910/a000095).

Hoertel N., Blanco C., Oquendo M.A. et al. (2017) A comprehensive model of predictors of persistence and recurrence in adults with major depression: Results from a national 3-year prospective study. J. Psychiatr. Res., 95: 19-27. doi: 10.1016 .

Khemakhem K., Boudabous J., Cherif L. et al. (2017) Impulsivity in adolescents with major depressive disorder: a comparative tunisian study. Asian J. Psychiatr., 28: 183-185. doi10.1016/j.ajp.2017.06.002.

Maruta N.O., Kutikov O.Y., Denysenko M. M., Kharchenko A.V. (2013) 2777 - Mechanisms of suicidogenesis in different variants of depressive disorders. Eur. Psychiatry, 28(1): 1 (https://doi.org/10.1016/S0924-9338(13)77367-X).

Marshal M.P., Dietz L.J., Friedman M.S. et al. (2011) Suicidality and depression disparities between sexual minority and heterosexual youth: a metaanalytic review. J. Adolesc. Health, 49(2): 115-123. doi: 10.1016/j.jadohealth.2011.02.005.

Nauta M.H., Festen H., Reichart C.G. et al. (2012) Preventing mood and anxiety disorders in youth: a multi-centre RCT in the high risk offspring of depressed and anxious patients. BMC Psychiatr., 12: 31 (https://doi.org/10.1186/1471244X-12-31).

Wilcox H.C., Wyman P.A. (2016) Suicide Prevention Strategies for Improving Population Health. Child Adolesc. Psychiatr. Clin. N. Am., 25(2): 219-33. doi: 10.1016/j.chc.2015.12.003

\section{Особенности суицидальных намерений среди пациентов с когнитивными нарушениями при депрессивных расстройствах}

\section{Н.А. Марута, С.А. Ярославцев}

Резюме. Цель - определение особенностей суицидальных намерений среди пациентов с когнитивными нарушениями при депрессивных расстройствах. Объект и методы исследования. Обследовано 362 пациента с когнитивными нарушениями при депрессивных расстройствах: 123 - с рекуррентными депрессивными расстройствами, $141-c$ биполярными аффективными расстройствами и 98 - с пролонгированной депрессивной реакцией. Использовали клинико-психопатологический, психометрический и статистический методы исследования. Результаты. Определены факторы суицидального риска у пациентов с когнитивными нарушениями при депрессивных расстройствах, которые включали особенности суицидальных намерений, идеаторные особенности суицидальных мыслей и характеристики возможной суицидальной попытки. Выводы. Указанные факторы суицидального риска могут выступать в качестве диагностических критериев и учитываться при создании психокоррекционных программ, направленных на редукцию суицидального риска.

Ключевые слова: когнитивные нарушения, депрессивные расстройства, суицидальный риск, рекуррентное депрессивное расстройство, биполярное депрессивное расстройство, пролонгированная депрессивная реакция.

\section{Features of suicide intentions among patients with cognitive impairments in depressive disorders}

\section{N.A. Maruta, S.A. Yaroslavtsev}

Summary. The aim of the study was to determine the characteristics of suicidal ideation among patients with cognitive impairment in depressive disorders. Object and methods. 362 patients with cognitive impairment in depressive disorders were examined: 123 with recurrent depressive disorder, 141 with bipolar affective disorder and 98 with prolonged depressive reaction. Clinical-psychopathological, psychometric and statistical research methods were used. Results. Suicide risk factors in patients with cognitive impairment in depressive disorders were identified, which included features of suicidal intentions, ideational features of suicidal thoughts and characteristics of presumed suicide attempt. Conclusion. Selected suicide risk factors can act as diagnostic criteria and can be taken into account creating psycho-correctional programs aimed at reducing suicide risk.

Key words: cognitive impairments, depressive disorders, suicidal risk, recurrent depressive disorder, bipolar depressive disorder, prolonged depressive reaction.

\section{Адреса для листування:}

Марута Наталія Олександрівна

дУ «Інститут неврології, психіатрії

та наркології НАМН України»

61068, Харків, вул. Академіка Павлова, 46

E-mail: mscience@ukr.net 